\title{
PENGARUH CORPORATE SOCIAL RESPONSIBILITY DAN KONFLIK KEPENTINGAN TERHADAP KONSERVATISME AKUNTANSI DENGAN RISIKO LITIGASI SEBAGAI PEMODERASI
}

\author{
Agcristina Collia Agata $^{1}$, Dwi Suhartini ${ }^{2}$, Astrini Aning Widoretno ${ }^{3}$ \\ ${ }^{1,2,3}$ Program Studi Akuntansi, Fakultas Ekonomi dan Bisnis, Universitas Pembangunan \\ Nasional "Veteran" Jawa Timur \\ colliaagata@gmail.com
}

\begin{abstract}
Abstrak
Penelitian memiliki tujuan untuk menguji dan menganalisis pengaruh Corporate Social Responsibility dan konflik kepentingan terhadap konservatisme akuntansi. Penelitian ini juga bertujuan untuk menguji dan menganalisis risiko litigasi memoderasi pengaruh Corporate Social Responsibility dan konflik kepentingan terhadap konservatisme akuntansi. Penelitian-penelitian terdahulu menunjukkan hasil yang tidak konsisten sehingga peneliti tertarik untuk meneliti kembali dua faktor yang mempengaruhi konservatisme akuntansi yaitu CSR dan konflik kepentingan dengan menambahkan variabel moderasi. Jenis penelitian ini adalah kuantitatif dengan data sekunder. Populasi dalam penelitian ini adalah perusahaan manufaktur sektor barang konsumsi primer yang terdaftar di BEI periode 2015-2019 yaitu sebanyak 88 perusahaan. Teknik pengambilan sampel menggunakan purposive sampling sehingga terpilih 50 observasi. Teknik pengumpulan data menggunakan studi dokumentasi dan analisis data yang digunakan yaitu SmartPLS 3.0. Hasil penelitian ini menunjukkan CSR berpengaruh positif terhadap konservatisme akuntansi, konflik kepentingan tidak berpengaruh terhadap konservatisme akuntansi, risiko Litigasi tidak mempu memoderasi CSR terhadap konservatisme akuntansi, dan risiko litigasi mampu memoderasi lebih tepatnya memperlemah konflik kepentingan terdahap konservatisme akuntansi.
\end{abstract}

Kata Kunci: Corporate Social Responsibility, Konflik Kepentingan, Konservatisme Akuntansi, Risiko Litigasi

\begin{abstract}
The purpose of this research is to test and analyse the Corporate Social Responsibility's influence and the conflict interest towards accounting conservatism. Apart from that, the other purpose is to test and analyse the moderation litigation risk of Corporate Social Responsibility's influence and the conflict interest towards accounting conservatism. Previous studies have shown inconsistent results so that researchers are interested in re-examining two factors that influence accounting conservatism, namely CSR and conflict of interest by adding moderating variables. This is a quantitative research using secondary data. The research population are 88 manufacturing companies for primary needs goods, which are listed in BEI for period 2015 until 2019. The sample collection technique uses purposive sampling until narrowed to 50 analysis units. The data collection technique uses SmartPLS 3.0 for documentation study and data analysis. The result of this research shows the positive influence of CSR on the accounting conservatism, conflict interest which is not affecting the accounting conservatism, litigation risk cannot be able to do the CSR moderation on accounting conservatism, and the litigation risk can be able to do the moderation which exactly weakening the conflict interest on the accounting conservatism
\end{abstract}

Keyword: Corporate social responsibility, Conflict of interest, accounting conservatism, and litigation risk. 


\section{PENDAHULUAN}

Setiap perusahaan wajib menerbitkan laporan keuangan untuk menunjukkan kinerja perusahaan. Tujuan pelaporan keuangan adalah memberikan informasi untuk pihak internal dan pihak eksternal seperti investor, kreditor, pemerintah, dan masyarakat. Informasi yang diberikan oleh perusahaan bersumber dari semua kegiatan operasional perusahaan dan harus sesuai dengan standar pelaporan keuangan. Standar Akuntansi Keuangan memberikan fleksibilitas kepada manajemen untuk menentukan metode yang digunakan dalam menyusun laporan keuangan. Akibat kebebasan dalam memilih metode akuntansi adalah angka-angka yang tersaji dalam laporan keuangan berbeda-beda (Iskandar \& Sparta, 2019).

Konservatisme akuntansi didefinisikan sebagai tindakan mempercepat mengakui beban dan memperlambat mengakui pendapatan sehingga laba yang dihasilkan tidak overstatement, hal ini mencerminkan bahwa perusahaan menerapkan konservatisme akuntansi dalam menyajikan angkaangka laporan keuangan. Konservatisme akuntansi dalam penyusunan laporan keuangan digunakan untuk menghadapi ketidakpastian kondisi ekonomi di masa mendatang. Menurut Suwardjono (2014:245) konservatisme merupakan sikap dalam mengambil keputusan dan menghadapi ketidakpastian di masa mendatang. Penerapan konservatisme dapat menjadi kendala dalam pelaporan keuangan, akan tetapi konservatisme akutansi bermanfaat untuk menghindari adanya kecurangan (Watts, 2003). Manipulasi laporan keuangan merupakan tindakan manajer dalam mengambil kesempatan yang umumnya dilakukan dengan menyajikan laba yang terlalu tinggi dan dapat membahayakan keberlangsungan hidup perusahaan. Lafond \& Watts (2007) berpendapat bahwa konservatisme akuntansi yang diterapkan dalam penyusunan laporan keuangan dapat meminimalisir asimetri informasi. Dalam mempertahankan eksistensi perusahaan tidak hanya menyajikan laporan keuangan yang baik dengan penerapan konservatisme akuntansi, tetapi perusahaan juga wajib menyajikan laporan nonkeuangan.

Penyajian laporan keuangan sebagai pertanggungjawaban kepada stakeholder dapat mengakibatkan perusahaan tidak memperhatikan tanggung jawab sosial karena hanya fokus pada tanggung jawab finansialnya. Tanggung jawab sosialnya dapat dikomunikasikan melalui pengungkapan Corporate Social Responsibility (CSR), oleh karena itu pemerintah mewajibkan perusahaan untuk menjalankan tanggung jawab sosialnya. Dengan adanya kewajiban untuk menjalankan CSR diharapkan dapat memberikan imbal balik kepada masyarakat dan lingkungan sekitar sebagai pengelolaan perusahaan yang baik. Perusahaan yang berorientasi pada CSR secara konsisten dengan manajerial untuk terlibat dalam praktik yang bermanfaat bagi sejumlah kelompok pemangku kepentingan yang berbeda. Kegiatan CSR yang telah dilakukan dan diungkapkan dalam laporan keuangan tahunan perusahaan dapat menciptakan nilai ekonomi dan perusahaan yang memiliki tingkat CSR yang tinggi akan menarik perhatian investor. Pengungkapan CSR memberikan peluang perusahaan di masa depan yang baik ketika memberikan kepeduliannya terhadap dampak yang ditimbulkan dari aktivitas perusahaan tersebut. Perusahaan yang memiliki reputasi baik tentunya tidak terlepas dari dukungan dan penilaian stakelohders terhadap kualitas annual reports yang disajikan perusahaan.

Konflik kepentingan adalah salah satu faktor yang mempengaruhi konservatisme akuntansi. Investor dan kreditor memiliki kepentingan yang berbeda, investor berkepentingan terhadap laba melalui pembayaran deviden yang berlebihan, sedangkan kreditor berkepentingan terhadap keuntungan di masa depan sehingga kreditor harus memastikan bahwa ketersediaan dana perusahaan aman (Paramita \& Cahyati, 2013). Perusahaan yang berada dalam konflik kepentingan antara investor dan kreditor akan menerapkan akuntansi yang lebih konservatif.

Risiko litigasi adalah faktor lain yang dapat mempengaruhi konservatisme akuntansi. Risiko litigasi didasarkan pada pandangan bahwa mendapatkan perlindungan secara hukum adalah hak investor dan kreditor. Risiko litigasi dapat timbul dari kreditor ketika perusahaan tidak memenuhi kewajibannya sesuai perjanjian yang telah disepakati. Risiko litigasi dapat menjadikan perusahaan lebih berhati-hati dalam melaporkan keuangannya ketika berada dalam kondisi keuangan yang tidak stabil (Wisuandari \& Putra, 2018). Pelaporan laba yang cenderung tinggi dapat memicu timbulnya risiko litigasi. Perusahaan melakukan pelaporan keuangan dengan konservatisme akuntansi untuk menghindari kerugian akibat litigasi tersebut, karena potensi risiko litigasi lebih tinggi ketika laba yang dilaporkan terlalu tinggi (Suryandari \& Priyanto, 2012). Pelaporan laba yang terlalu tinggi dengan akuntansi konservatif dapat membahayakan kreditor karena kreditor tidak dapat menilai kemampuan perusahaan dalam membayar hutangnya.

Beberapa penelitian yang menguji pengaruh CSR dan konflik kepentingan terhadap konservatisme akuntansi memiliki hasil yang berbeda-beda, hasil penelitian Anagnostopoulou dkk. (2020) menunjukkan bahwa CSR tidak memiliki pengaruh terhadap tingkat konservatisme akuntansi. Hasil berbeda ditunjukkan oleh Shen dkk. (2020) bahwa tingkat CSR tinggi memiliki tingkat 
konservatisme akuntansi yang tinggi. Hasil penelitian Paramita \& Cahyati (2013) menyatakan bahwa konflik kepentingan berpengaruh terhadap konservatisme akuntansi. Namun berbeda dengan hasil penelitian Wisuandari \& Putra (2018) yang menyatakan bahwa konflik kepentingan tidak memiliki pengaruh pada konservatisme akuntansi. Beberapa penelitian yang menggunakan risiko litigasi sebagai variabel moderasi juga menunjukkan hasil yang berbeda. Menurut Paramita \& Cahyati (2013) risiko litigasi memoderasi (menguatkan) hubungan konflik kepentingan pada konservatisme akuntansi, sedangkan hasil penelitian Suryandari \& Priyanto (2012) menunjukkan tingginya risiko litigasi akan mdmperlemah konflik kepentingan terhadap konservatisme akuntansi.

Berdasarkan permasalahan diatas, peneliti tertarik untuk menguji kembali pengaruh CSR dan konflik kepentingan terhadap konservatisme akuntansi dengan risiko litigasi sebagai pemoderasi.

\section{TINJAUAN PUSTAKA}

\section{Teori Keagenan (Agency Theory)}

Jensen \& Meckling (1976) mendefinisikan agency theory sebagai perjanjian antara principal dengan agen, dimana principal mempercayakan agen untuk melakukan kegiatan operasional perusahaan dengan sumber daya yang telah disediakan, dan tentu saja agen memiliki wewenang untuk mengambil alih keputusan dalam mengelola perusahaan. Perbedaan kepentingan antara principal dan agen dapat berpengaruh pada kualitas laba yang dihasilkan. Agen sebagai pemilik informasi yang lebih banyak jika dibandingkan dengan principal, sehingga mereka dapat memaksimalkan kepentingannya dengan menyajikan laba dengan overstatement. Penerapan prinsip konservatisme akuntansi dapat mencegah terjadinya hal tersebut dengan menyajikan laba yang tidak terlalu tinggi sehingga informasi yang disajikan berkualitas untuk dijadikan dasar pengambilan keputusan.

\section{Teori Akuntansi Positif}

Teori akuntansi positif digunakan dalam menganalisis kondisi di masa yang akan datang dengan menggunakan pengetahuan akuntansi, kemampuan, dan kebijakan akuntansi. Watts \& Zimmerman (1990) mendefinisikan teori akuntansi positif sebagai teori yang bersifat meramalkan dan digunakan manajer dalam membuat keputusan mengenai kebijakan akuntansi, dimana prediksi tersebut didasarkan pada hubungan keagenan antara manajer dan pihak principal. Akuntansi positif memberikan kebebasan kepada setiap perusahaan untuk memilih kebijakan akuntansi yang tersedia, sehingga manajemen dapat bebas dalam memilih kebijakan akuntansi yang dapat memaksimalkan keuntungan atau bersifat oportunistik (Mulyani \& Juvenrio, 2017).

\section{Teori Stakeholder (Stakeholder Theory)}

Stakeholder yaitu pihak yang memiliki hubungan baik dengan perusahaan secara langsung atau tidak langsung dan bersifat mempengaruhi atau dipengaruhi. Pihak-pihak yang dimaksud adalah pemerintah, masyarakat sekitar, lembaga pengamat lingkungan sosial, karyawan, konsumen, dan perusahaan lainnya yang keberadaannya bersifat mempengaruhi dan dipengaruhi oleh perusahaan (Sari \& Priyadi, 2020).

Konsep stakeholder theory mulai dikenal pada tahun 1970an. Dalam mencapai tujuan perusahaan dan mempertahankan kelangsungan hidupnya dibutuhkan dukungan dari stakeholder, perusahaan harus mempertimbangkan manfaat dari keberadaan perusahaan tersebut dan mempertimbangkan kepentingan stakeholders lainnya, karena perusahaan yang menjalankan bisnisnya sesuai dengan etika bisnis akan dinilai positif oleh pihak eksternal. Implikasi stakeholder theory dalam penelitian ini adalah untuk memperoleh dukungan dari stakeholders. Transaparansi laporan keuangan adalah salah satu hal yang diharapkan oleh stakeholders, oleh karena itu penyajian laporan keuangan dapat dilakukan dengan menerapkan prinsip konservatisme. Penerapan konservatisme akuntansi dalam pelaporan keuangan juga dapat mencegah adanya manipulasi laporan keuangan dan mengurangi biaya litigasi (Cheng \& Kung, 2016). Risiko litigasi dapat merugikan perusahaan, oleh karena itu perusahaan harus menerapkan metode akuntansi yang tepat untuk menghindari risiko litigasi. Perusahaan dapat menggunakan pengungkapan CSR dalam menjaga kepercayaan stakeholder, untuk mempertahankan kepercayaan yang telah diberikan maka perusahaan akan lebih konservatif dalam menyajikan laporan keuangan.

\section{Corporate Social Responsibility (CSR)}

CSR adalah tanggung jawab sosial yang dilakukan oleh perusahaan sesuai dengan peraturan yang berlaku. Tanggung jawab sosial ini bersifat wajib bagi perusahaan yang menjalankan kegiatan bisnisnya dibidang dan/atau berkaitan dengan sumber daya alam. Sari \& Priyadi (2020) mendefinisikan CSR sebagai komitmen perusahaan ketika menjalankan aktivitas bisnisnya dengan memperhatikan tanggung jawab sosial bagi lingkungan sekitar dan berperan aktif dalam pengembangan ekonomis secara berkelanjutan. Avesani (2020) menyatakan bahwa CSR merupakan alat yang diadopsi oleh perusahaan untuk bertanggung jawab atas dampak sosial yang terdeteksi, perusahaan harus memberikan manfaat sosial yang lebih tinggi dibandingkan dampak 
sosialnya. Definisi tersebut menunjukkan bahwa pengungkapan informasi kegiatan tanggung jawab sosial adalah bentuk tindakan sesuai etika bisnis yang berorientasi meningkatkan ekonomi dan kualitas hidup masyarakat setempat serta karyawan (Sari \& Priyadi, 2020).

\section{Konflik Kepentingan}

Berdasarkan teori keagenan (agency theory) setiap perusahaan memiliki kontrak antara principal dengan agen, yang masing-masing pihak memiliki perbedaan kepentingan. Konflik keagenan dapat terjadi antara pemegang saham dengan manajer, kreditor dengan manajer, dan pemegang saham dengan kreditor. Masalah yang menimbulkan konflik pemegang saham dengan kreditor salah satunya mengenai kebijakan deviden. Masalah timbul ketika pembayaran deviden kas yang besar kepada shareholders akan mengurangi aset untuk bondholders, sedangkan bondholders menginginkan perusahaan memiliki aset yang cukup untuk memastikan perusahaan dapat melunasi hutangnya (Suryandari \& Priyanto, 2012). Untuk mengatasi masalah tersebut, kreditor menuntut manajemen menerapkan konservatisme akuntansi agar deviden yang dibayarkan kepada shareholders tidak terlalu tinggi dengan tidak menyajikan laba yang terlalu tinggi (Wisuandari \& Putra, 2018).

\section{Risiko Litigasi}

Risiko litigasi adalah risiko perusahaan yang berkaitan dengan hukum oleh pihak-pihak yang perkepentingan. Penyebab umum risiko litigasi adalah kerugian investor akibat penyajian laba yang tinggi pada perusahaan dan tidak dapat dipertanggung jawabkan (Sinambela \& Almilia, 2018). Untuk menghindari risiko litigasi yang dapat menyebabkan kerugian perusahaan, manajer dapat menyajikan laporan keuangan dengan lebih konservatif, karena tingkat risiko litigasi yang tinggi disebabkan oleh laba yang overstatement.

\section{Konservatisme Akuntansi}

Givoly \& Hayn (2000) menyampaikan bahwa konservatisme dalam Glosarium Pernyataan Konsep No. 2 FASB didefinisikan sebagai prudent reaction dalam menghadapi ketidakpastian pada perusahaan agar ketidakpastian tersebut dapat dikendalikan dengan baik dengan risiko yang telah dipertimbangkan. Suwardjono (2014:245) mendefinisikan konservatisme sebagai sikap untuk mengantisipasi dan mengambil keputusan atas ketidakpastian yang terjadi di masa yang akan datang. Watts (2003) juga menjelaskan tentang konservatisme akuntansi perusahaan, dimana konservatisme adalah upaya yang berkaitan dengan penjelasan kontrak (contracting explanation), litigasi (litigation), pajak (taxation), dan regulator agar laporan keuangan disusun dengan konservatif.
Ketidakpastian ekonomi dapat dihadapi dengan penerapan akuntasi yang konservatif dalam penyajian laporan keuangan. Konservatisme adalah upaya dalam menentukan metode akuntansi untuk mengakui pendapatan lebih lambat serta mengakui biaya lebih cepat. Sesuai dengan SAK, perusahaan diberikan kebebasan dalam menentukan metode akuntansi yang akan diterapkan. Pilihan-pilihan metode akuntansi mempengaruhi angka yang dimuat dalam laporan keuangan, dengan menerapkan konservatisne akuntansi akan memperlihatkan laba yang fluktuatif sehingga bisa membuat berkurangnya kemampuan memprediksi laba untuk memprediksi aliran kas perusahaan tersebut pada masa depan (Andini dkk., 2020).

\section{METODE}

Penelitian ini adalah penelitian metode kuantitatif. Menurut Sugiyono (2017:8) metode penelitian kuantitatif adalah metode penelitian yang digunakan untuk meneliti populasi atau sampel tertentu. Populasi dalam penelitian ini adalah perusahaan manufaktur sektor barang konsumsi primer (consumer non-cyclicals) yang terdaftar di BEI tahun 2015-2019 terdapat 88 perusahaan. Metode pengambilan sampel dalam penelitian ini dengan metode purposive sampling. Berdasarkan kriteria yang ditetapkan, terdapat 10 perusahaan yang memenuhi kriteria untuk dijadikan sampel penelitian selama periode penelitian 5 tahun sehingga diperoleh 50 total observasi. Peneliti mengambil populasi pada perusahaan sektor barang konsumsi primer atas pertimbangan bahwa perusahaan tersebut sebagai salah satu penggerak ekonomi nasional.

Instrumen pengukuran CSR Indeks yang digunakan pada penelitian ini mengacu pada penelitian Warislan dkk. (2018) yaitu item pengungkapan CSR dalam penelitian diberi skor 1 jika indikator yang diungkapkan ada dalam annual reports, dan diberi skor 0 jika indikator tidak diungkapkan di dalam annual reports dan kemudian dibagi dengan total item pengungkapan. Konflik kepentingan diukur berdasarkan kebijakan deviden. Konservatisme akuntansi diukur dengan nilai akrual. Dan risiko litigasi diukur dengan Debt to Equity Ratio (DER).

Data dapat diperoleh dari situs resmi BEI sedangkan teknik pengumpulan data dilakukan dengan dokumentasi. Analisis data dalam penelitian ini menggunakan pendekatan Partial Least Square (PLS) dengan software SmartPLS 3.0. 


\section{HASIL DAN PEMBAHASAN}

\section{Hasil Statistik Deskriptif}

Tabel 1 Hasil Statistik Deskriptif

\begin{tabular}{|l|c|c|c|c|c|}
\hline Variabel & N & Minimum & Maximum & Mean & $\begin{array}{c}\text { Std. } \\
\text { Deviation }\end{array}$ \\
\hline CSR & 50 & 0,05 & 0,29 & 0,15 & 0,06 \\
\hline $\begin{array}{l}\text { Konflik } \\
\text { Kepentingan }\end{array}$ & 50 & 0,00 & 0,43 & 0,07 & 0,11 \\
\hline $\begin{array}{l}\text { Konservatisme } \\
\text { Akuntansi }\end{array}$ & 50 & $-0,20$ & 0,08 & $-0,03$ & 0,06 \\
\hline Risiko Litigasi & 50 & 0,16 & 2,68 & 0,99 & 0,70 \\
\hline
\end{tabular}

Berdasarkan tabel 1 diketahui bahwa CSR, konservatisme akuntansi, dan risiko litigasi memiliki nilai standar deviasi < nilai rata-rata, hal ini mencerminkan bahwa data dalam penelitian adalah data homogen. Sedangkan konflik kepentingan memiliki nilai standar deviasi > nilai rata-rata mengindikasikan bahwa konflik kepentingan relatif berbeda dalam setiap perusahaan.

\section{Menilai Outer Model}

\section{Penilaian Convergent Validity}

Convergent validity adalah nilai loading factor untuk mengetahui seberapa valid model pengukuran yang dinilai berdasarkan hubungan antara variabel yang diukur dengan software PLS. Jika nilai convergent validity lebih dari 0,7 dengan konstruk yang diukur maka indikator tersebut dapat dinyatakan valid.

Berikut adalah hasil pengujian kualitas data dengan convergent validity yang dilihat dari nilai loading factor.

Tabel 2 Outer Loading

\begin{tabular}{|l|l|l|}
\hline \multicolumn{1}{|c|}{ Variabel } & Nilai Loading & \multicolumn{1}{c|}{ Hasil } \\
\hline CSR (X1) & 1,00 & Valid \\
\hline Konflik Kepentingan (X2) & 1,00 & Valid \\
\hline Konservatisme Akuntansi (Y) & 1,00 & Valid \\
\hline Risiko Litigasi (Z) & 1,00 & Valid \\
\hline CSR * Risiko Litigasi (Moderating Effect 1) & 0,71 & Valid \\
\hline $\begin{array}{l}\text { Konflik Kepentingan * Risiko Litigasi (Moderating } \\
\text { Effect 2) }\end{array}$ & 0,89 & \\
\hline Sumber: Data diolah dengan SmartPLS & \multicolumn{2}{|l}{} \\
\hline
\end{tabular}

Berdasarkan hasil pengujian tabel 2 menunjukkan bahwa semua variabel memenuhi kriteria valid dalam penelitian ini karena nilai loading factor lebih dari 0,7 .

\section{Discriminant Validity}

Discriminant validity digunakan untuk mengetahui setiap konsep dari semua variabel berbeda dengan variabel lainnya yang ditunjukkan dari nilai cross loading dan akar kuadrat dari AVE.

Tabel 3 Discriminant Validity

\begin{tabular}{|l|l|l|l|l|l|l|}
\hline & $\mathbf{X 1}$ & $\mathbf{X} \mathbf{2}$ & $\mathbf{Y}$ & $\mathbf{Z}$ & $\mathbf{X} \mathbf{1}^{\star} \mathbf{Z}$ & $\mathbf{X 2} \mathbf{Z}^{\star} \mathbf{Z}$ \\
\hline $\mathrm{X} 1$ & $\mathbf{1 , 0 0}$ & 0,41 & 0,13 & 0,20 & 0,04 & 0,27 \\
\hline $\mathrm{X} 2$ & 0,41 & $\mathbf{1 , 0 0}$ & $-0,13$ & 0,07 & 0,34 & 0,59 \\
\hline $\mathrm{Y}$ & 0,13 & $-0,13$ & $\mathbf{1 , 0 0}$ & 0,05 & $-0,07$ & $-0,31$ \\
\hline $\mathrm{Z}$ & 0,20 & 0,07 & 0,05 & $\mathbf{1 , 0 0}$ & 0,06 & $-0,11$ \\
\hline $\mathrm{X} 1^{*} \mathrm{Z}$ & 0,04 & 0,34 & $-0,07$ & 0,06 & $\mathbf{1 , 0 0}$ & 0,33 \\
\hline $\mathrm{X} 2^{*} \mathrm{Z}$ & 0,27 & 0,59 & $-0,31$ & $-0,11$ & 0,33 & $\mathbf{1 , 0 0}$ \\
\hline
\end{tabular}

Berdasarkan tabel 3 diatas diketahui bahwa nilai cross loading adalah nilai yang dicetak tebal, semua variabel memiliki nilai 1,00 yang artinya memiliki nilai paling besar untuk variabel yang dibentuk dan tidak pada variabel lain. Sehingga dalam penelitian ini memiliki validitas diskriminan yang baik.

\section{Composite Reliability}

Composite reliability menunjukan reliabilitas data dalam penelitian ini. Nilai komposit reliabilitas yang baik apabila nilai tersebut $>0,7$. Hasil uji dapat diketahui sebagai berikut:

Tabel 4 Composite Reliability

\begin{tabular}{|l|c|}
\hline & $\begin{array}{c}\text { Composite } \\
\text { Reliability }\end{array}$ \\
\hline $\mathrm{X} 1$ & 1,00 \\
\hline $\mathrm{X} 2$ & 1,00 \\
\hline $\mathrm{Y}$ & 1,00 \\
\hline $\mathrm{Z}$ & 1,00 \\
\hline $\mathrm{X} 1 * \mathrm{Z}$ & 1,00 \\
\hline \multicolumn{2}{|c|}{1,00} \\
\hline $\mathrm{X} 2 * \mathrm{Z}$
\end{tabular}

Berdasarkan tabel 4 menunjukkan bahwa variabel dalam penelitian ini memiliki nilai composite reliability $>0,7$ sehingga dapat dinyatakan bahwa keseluruhan outer model telah memenuhi syarat.

\section{R-Square}

Nilai $R$-square digunakan untuk mengetahui pengaruh variabel independen tertentu terhadap variabel dependen. R-square menjelaskan keragaman konstruk endogen yang mampu dijelaskan oleh konstruk-konstruk eksogen secara serentak (Ghozali \& Latan, 2015:78). Hasil perhitungan $R^{2}$ tergolong lemah karena nilai $<0,25$. 
Tabel 5 Nilai $R$-Square

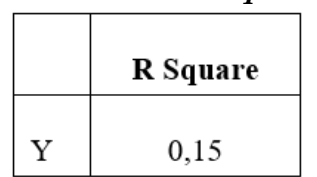

Sumber: Data diolah dengan SmartPLS

Tabel 5 menunjukkan bahwa konservatisme akuntansi dapat dijelaskan oleh variabel CSR, konflik kepentingan, dan risiko litigasi sebagai variabel moderasi sebesar $15 \%$. Sedangkan sisanya $85 \%$ dipengaruhi oleh variabel lain yang tidak diteliti dalam penelitian ini.

\section{F-Square}

$F$-square digunakan untuk mengetahui seberapa baik model dalam penelitian ini. Nilai $f$ square menunjukkan lebih dari 0,02 dan kurang dari 0,15 yang artinya memiliki pengaruh yang kecil pada inner model.

Tabel 6 Nilai F-Square

\begin{tabular}{|l|c|}
\hline & $\mathbf{Y}$ \\
\hline $\mathrm{X} 1$ & 0.06 \\
\hline $\mathrm{X} 2$ & 0.00 \\
\hline $\mathrm{Z}$ & 0.00 \\
\hline $\mathrm{X} 1 * \mathrm{Z}$ & 0.00 \\
\hline $\mathrm{X} 2 * \mathrm{Z}$ & 0.11 \\
\hline
\end{tabular}

Sumber: Data diolah dengan SmartPLS

\section{Pengujian Path Coefficients}

Pengujian ini digunakan untuk mengetahui efek moderasi penelitian dengan Partial Least Square dibantu software SmartPLS 3.0

Tabel 7 Hasil Path Coefficients

\begin{tabular}{|l|c|c|c|c|c|}
\hline & $\begin{array}{c}\text { Original } \\
\text { Sample } \\
(\boldsymbol{O})\end{array}$ & $\begin{array}{c}\text { Sample } \\
\text { Mean } \\
(\boldsymbol{M})\end{array}$ & $\begin{array}{c}\text { Standard } \\
\text { Deviation } \\
(\text { STDEV })\end{array}$ & $\begin{array}{c}\text { T Statistics } \\
\text { (O/STDEV })\end{array}$ & $\begin{array}{c}\boldsymbol{P} \\
\text { Values }\end{array}$ \\
\hline $\begin{array}{l}\text { CSR } \\
\text { Konservatisme } \\
\text { Akuntansi }\end{array}$ & 0,25 & 0,27 & 0,11 & 2,35 & 0,02 \\
\hline $\begin{array}{l}\text { Konflik } \\
\text { Kepentingan -> } \\
\text { Konservatisme } \\
\text { Akuntansi }\end{array}$ & $-0,01$ & $-0,04$ & 0,18 & 0,08 & 0,94 \\
\hline $\begin{array}{l}\text { X1*Z }-> \\
\text { Konservatisme } \\
\text { Akuntansi }\end{array}$ & 0,08 & 0,08 & 0,19 & 0,40 & 0,69 \\
\hline $\begin{array}{l}\text { X2*Z -> } \\
\text { Konservatisme } \\
\text { Akuntansi }\end{array}$ & $-0,44$ & $-0,42$ & 0,20 & 2,23 & 0,03 \\
\hline
\end{tabular}

Berdasarkan tabel 7 dapat dijelaskan hasil pengujian dilihat dari $P$ Values dengan tingkat signifikan yang digunakan sebesar 5\% sehingga menghasilkan t-table sebesar 1,96. Syarat diterima hipotesis yaitu $T$-Statistic $>1,96$ dengan nilai $P$ Values <0,05:

1. Pengaruh $C S R$ terhadap konservatisme akuntansi jika dilihat dari parameter original sample memiliki nilai 0,25 dan nilai $T$-Statistic 2,35 > 1,96 sedangkan $P$ Values sebesar $0,02<0,05$.

2. Pengaruh positif konflik kepentingan terhadap konservatisme akuntansi jika dilihat dari parameter original sample memiliki nilai $-0,01$ dan nilai $T$-Statistic $0,08<1,96$ sedangkan $P$-Values $0,94>$ 0,05 .

3. Pengaruh risiko litigasi yang memoderasi Corporate Social Responsibility terhadap konservatisme akuntansi jika dilihat dari parameter original sample memiliki nilai 0,08 dan nilai T-Statistic $0,40<1,96$ sedangkan $P$-Values $0,69>0,05$.

4. Pengaruh risiko litigasi yang memoderasi konflik kepentingan terhadap konservatisme akuntansi jika dilihat dari parameter original sample memiliki nilai -0,44 dan nilai $T$-Statistic 2,23>1,96 sedangan $P$-Values $0,03<0,05$.

\section{Pengaruh Corporate Social Responsibility Terhadap Konservatisme Akuntansi}

Berdasarkan analisis menunjukkan bahwa CSR berpengaruh terhadap konservatisme akuntansi. Hal tersebut mencerminkan bahwa perusahaan yang melaksanakan CSR memiliki kontrol yang lebih baik terhadap penyajian laporan keuangan karena dianggap menjalankan aktivitas bisnis sesuai dengan etika.

Dalam stakeholder theory perusahaan memerlukan dukungan dari stakeholders melalui adanya pengungkapan CSR. Stakeholders mendukung keberlangsungan hidup perusahaan jika pengungkapan yang disajikan mencakup aktivitas finansial dan non-finansial yang diharapkan. Pengungkapan ini dapat berpengaruh terhadap penilaian investor dalam menciptakan nilai perusahaan. Dalam penelitian ini perusahaan secara konsisten melakukan pengungkapan CSR, dan perusahaan dengan tingkat CSR tinggi lebih konservatif dalam menyajikan laporan keuangan tahunan.

Hasil ini sejalan dengan penelitian Shen dkk. (2020) dan Cheng \& Kung (2016) yang menunjukkan tingginya pengungkapan CSR berpengaruh positif terhadap konservatisme akuntansi. Dan hasil tidak sejalan dengan penelitian Anagnostopoulou dkk. (2020) yang menunjukkan 
tingkat CSR tidak berpengaruh terhadap konservatisme akuntansi.

\section{Pengaruh Konflik Kepentingan Terhadap} Konservatisme Akuntansi

Berdasarkan analisis, konflik kepentingan tidak berpengaruh terhadap konservatisme akuntansi. Konflik kepentingan dalam agency theory dinilai dari kebijakan deviden atau pendanaan. Kebijakan deviden berkaitan dengan kebijakan besarnya laba perusahaan yang dibagikan kepada shareholder. Pembagian return yang tinggi dapat menjadi daya tarik investor, maka tingkat konservatisme akuntansi juga semakin tinggi.

Hasil dalam penelitian ini mencerminkan bahwa konflik kepentingan bertolak belakang dengan agency theory. Dalam hal ini yang dijadikan dasar konflik kepentingan adalah kebijakan deviden, dan tidak ada pembayaran deviden yang berlebih pada investor sehingga tidak terdapat kekhawatiran dari pihak kreditor terkait pembayaran yang tinggi kepada investor, sehingga konflik kepentingan tidak berpengaruh terhadap konservatisme akuntansi. Besar atau kecil konflik kepentingan terkait kebijakan deviden tidak mempengaruhi penerapan konservatisme akuntansi.

Hasil ini didukung oleh penelitian Wisuandari \& Putra (2018) dan Andini dkk. (2020) yang menunjukkan konflik kepentingan tidak memiliki pengaruh terhadap konservatisme akuntansi. Dan tidak didukung penelitian Paramita \& Cahyati (2013) dan Suryandari \& Priyanto (2012) yang menunjukkan konflik kepentingan memiliki pengaruh positif pada konservatisme akuntansi.

\section{Pengaruh Corporate Social Responsibility yang Dimoderasi oleh Risiko Litigasi Terhadap Konservatisme Akuntansi}

Berdasarkan analisis menunjukkan bahwa risiko litigasi tidak mampu memoderasi pengaruh CSR terhadap konservatisme akuntansi. Dalam stakeholder theory untuk mendapatkan dukungan dari stakeholder maka perusahaan harus menjalankan aktivitasnya sesuai dengan etika bisnis dan lebih konservatif dalam menyajikan laporan keuangan. Sehingga perusahaan yang memiliki CSR tinggi akan lebih konservatif dalam pelaporan annual reports. Dengan menerapkan konservatisme akuntansi dapat mencegah adanya risiko litigasi, karena risiko litigasi dapat merusak citra perusahaan, dan tentunya citra yang tidak baik akan bertolak belakang dengan harapan stakeholder.

Penelitian ini menunjukkan bahwa besar kecilnya tingkat risiko litigasi tidak dapat mempengaruhi CSR terhadap konservatisme akuntansi. Hasil ini diperkuat oleh penelitian Ball, dkk. (2000) bahwa tingkat konservatisme akuntansi cenderung lebih rendah apabila dikaitkan dengan hukum yang berlaku. Dan tidak didukung penelitian
Watts (2003) yang menunjukkan hasil penerapan konservatisme akuntansi dapat mengurangi ancaman litigasi.

Pengaruh Konflik Kepentingan yang Dimoderasi oleh Risiko Litigasi Terhadap Konservatisme Akuntansi

Berdasarkan analisis menunjukkan risiko litigasi mampu memoderasi pengaruh konflik kepentingan terhadap konservatisme akuntansi. Hasil penelitian menunjukkan bahwa risiko litigasi bersifat memperlemah pengaruh konflik kepentingan terhadap konservatisme akuntansi. Hal ini menunjukkan bahwa tingkat risiko litigasi yang tinggi memperlemah pengaruh konflik kepentingan terhadap konservatisme akuntansi. Perusahaan yang memiliki konflik kepentingan apabila mempertimbangkan risiko litigasi akan tidak berpengaruh terhadap konservatisme akuntansi, hal ini dimungkinkan perusahaan sudah melakukan antisipasi adanya konflik kepentingan mengenai kebijakan deviden.

Hasil ini didukung oleh penelitian Suryandari \& Priyanto (2012) yang menunjukkan adanya risiko litigasi mampu memoderasi (melemahkan) hubungan konflik kepentingan dengan konservatisme akuntansi. Dan tidak didukung dengan penelitian Paramita \& Cahyati (2013) bahwa adanya risiko litigasi dapat menguatkan konflik kepentingan pada konservatisme akuntansi.

\section{PENUTUP}

\section{Simpulan}

Berdasarkan analisis dan pengujian yang telah dibahas dalam bab sebelumnya, dapat disimpulkan bahwa:

1. CSR berpengaruh positif terhadap konservatisme akuntansi. Perusahaan yang melakukan pemenuhan pengungkapan CSR akan menerapkan prinsip konservatisme akuntansi sehingga informasi yang disajikan berkualitas, dan konservatisme akuntansi dapat mempertahankan kepercayaan stakeholder terhadap perusahaan.

2. Konflik kepentingan tidak berpengaruh terhadap konservatisme akuntansi. Tidak terjadi konflik kepentingan karena tidak ada pembayaran deviden yang berlebih pada investor dan tidak ada kekhawatiran dari kreditor atas pembayaran deviden yang berlebih. Jadi besar atau kecil konflik kepentingan yang terjadi seputar kebijakan deviden tidak mempengaruhi konservatisme akuntansi.

3. Risiko litigasi tidak mampu memoderasi CSR terhadap konservatisme akuntansi. 
Tingginya tingkat risiko litigasi tidak menjamin dapat mengontrol konservatisme akuntansi.

4. Risiko litigasi memoderasi (memperlemah) konflik kepentingan terhadap konservatisme akuntansi. Tingginya tingkat risiko litigasi dapat menjadi rintangan adanya konflik kepentingan terhadap konservatisme akuntansi.

\section{Saran}

1. Penelitian selanjutnya harap menggunakan jenis perusahaan lainnya seperti perusahaan sektor kesehatan, properti \& real estate, teknologi, dan infrastruktur.

2. Penelitian selanjutnya dapat menambahkan variabel lain seperti kepemilikan manajerial, leverage, dan ukuran perusahaan.

3. Untuk penelitian selanjutnya dapat menambahkan pengukuran conservatism misalnya dengan market to book ratio. Dan jika meneliti konflik kepentingan disarankan dari konflik kebijakan hutang dan kebijakan investasi.

\section{DAFTAR PUSTAKA}

Anagnostopoulou, S. C., Tsekrekos, A. E., \& Voulgaris, G. (2020). Accounting conservatism and corporate social responsibility. British Accounting Review, $x x x x$, 100942. https://doi.org/10.1016/j.bar.2020.100942

Andini, N., Romus, M., \& Yanti. (2020). Analisis Faktor Yang Berpengaruh Terhadap Konservatisme Akuntansi Pada Perusahaan Yang Terdaftar Di Jakarta Islamic Index (JII) Periode Desember 2015 - November 2018. Jurnal Al Iqtishad, 2, 73-99.

Avesani, M. (2020). Sustainability, sustainable development, and business sustainability. In Life Cycle Sustainability Assessment for Decision-Making: Methodologies and Case Studies. Elsevier Inc. https://doi.org/10.1016/B978-0-12-8183557.00002-6.

Ball, Ray, and Lakshmanan, Shivakumar, (2002). Earnings Quality in U.K. 12 Private Firms, Working Paper, London Business School.

Cheng, C. L., \& Kung, F. H. (2016). The effects of mandatory corporate social responsibility policy on accounting conservatism. Review of Accounting and Finance, 15(1), 2-20.
https://doi.org/10.1108/RAF-12-2014-0135

Ghozali, I., \& Latan, H. (2015). Partial Least Squares: Konsep, Teknik, dan Aplikasi Menggunakan Program SmartPLS 3.0 untuk Penelitian Empiris (Edisi 2). Semarang: Badan Penerbit Universitas Diponegoro.

Givoly, D., \& Hayn, C. (2000). The Changing TimeSeries Properties of Earnings, Cash Flows and Accruals. Journal of Accounting and Economics, 29, 287-320.

Iskandar, O. R., \& Sparta, S. (2019). Pengaruh Debt Covenant, dan Political Cost Terhadap Konservatisme Akuntansi. Equity, 22(1), 47. https://doi.org/10.34209/equ.v22i1.896

Jensen, M. C., \& Meckling, W. H. (1976). Theory Of The Firm: Managerial Behavior, Agency Costs And Ownership Structure. Journal of Financial Economics, Vol. 3 (4), 305-360.

LaFond, R., \& Watts, R. L. (2007). The Information Role of Conservatism. The Accounting Review, Vol. 83. https://doi.org/https://doi.org/10.2139/ssrn.92 1619

Mulyani, M., \& Juvenrio. (2017). Konservatisme Akuntansi dan Faktor yang Mempengaruhi (Suatu Analisis terhadap Biaya Litigasi, Leverage, dan Growth Opportunities). Jurnal Analisa Akuntansi dan Perpajakan, 1(2).

Paramita, F., \& Cahyati, A. (2013). Pengaruh Konflik Kepentingan Terhadap Konservatisme Akuntansi Dengan Risiko Litigasi Dan Tipe Strategi Sebagai Variabel Pemoderasi. JRAK: Jurnal Riset Akuntansi \& Komputerisasi Akuntansi, 4(02). https://doi.org/10.33558/jrak.v4i2.1336

Sari, Y. A., \& Priyadi, M. (2020). Faktor-Faktor Yang Mempengaruhi Pengungkapan Corporate Social Responsibility Pada Perusahaan Manufaktur. Jurnal Ilmu Dan Riset Akuntansi (JIRA), 9 (4)(1).

Shen, X., Ho, K. C., Yang, L., \& Wang, L. F. S. (2020). Corporate social responsibility, market reaction and accounting conservatism. Kybernetes, 71903199. https://doi.org/10.1108/K-01-2020-0043

Sinambela, M. O. E., \& Almilia, L. S. (2018). Faktor-faktor yang mempengaruhi konservatisme akuntansi. Jurnal Ekonomi Dan Bisnis, 21(2), 289-312. https://doi.org/10.24914/jeb.v21i2.1788

Sugiyono. (2017). Metode Penelitian Kuantitatif, Kualitatif, dan $R \& D$. Penerbit Alfabeta. 
Suryandari, E., \& Priyanto, R. E. (2012). Pengaruh Risiko Litigasi dan Tingkat Kesulitan Keuangan Perusahaan terhadap Hubungan antara Konflik Kepentingan dan Konservatisme Akuntansi. Jurnal Akuntansi Dan Investasi, 12(2), 161-174. http://journal.umy.ac.id/index.php/ai/article/v iew/681

Suwardjono. (2014). Teori Akuntansi dan Perekayasaan Pelaporan Keuangan (Edisi Ketiga). Yogyakarta: BPFE.

Warislan, P., Putra, W. E., \& Tiswiyanti, W. (2018). Pengaruh Konservatisme Akuntansi Dan Pengungkapan Corporate Social Responsibility (CSR) Terhadap Manajemen Laba (Studi Empiris Pada Perusahaan Pertambangan Yang Terdaftar Di Bursa Efek Indonesia Periode 2015-2017). Jurnal Akuntansi Dan Auditing, 15(2), 121-243.

Watts, R. L. (2003). Conservatism in Accounting Part I: Explanations and Implications. Accounting Horizons, 17(3). https://doi.org/10.2139/ssrn.414522

Watts, R. L., \& Zimmerman, J. L. (1990). Positive Accounting Theory: A Ten Year Perspective. The Accounting Review, 65(1), 131-156.

Wisuandari, N. K. P., \& Putra, I. N. W. A. (2018). Pengaruh Tingkat Kesulitan Keuangan dan Konflik Kepentingan pada Konservatisme Akuntansi dengan Risiko Litigasi Sebagai Pemoderasi. E-Jurnal Akuntansi, 23 (2), 1521-1547.

https://doi.org/10.24843/EJA.2018.v23.i02.p2 7 